Sharif University of Technology
Scientia Iranica
SCIENTIA
IRAN I CA
Transactions A: Civil Engineering
www.scientiairanica.com

\title{
Prediction of lightweight aggregate concrete compressive strength using ultrasonic pulse velocity test through gene expression programming
}

\author{
M.A. Hadianfard* and S. Jafari \\ Department of Civil and Environmental Engineering, Shiraz University of Technology, Modarres Blvd, Shiraz, P.O. Box 71555313 , \\ Iran.
}

Received 14 February 2015; received in revised form 27 June 2015; accepted 15 September 2015

\author{
KEYWORDS \\ Non-destructive test; \\ Ultrasonic pulse \\ velocity; \\ Gene expression \\ programming; \\ Light weight aggregate \\ concrete; \\ Prediction of concrete \\ compressive strength.
}

\begin{abstract}
The use of lightweight structural concrete to reduce the weight of earthquake resistant buildings is very useful, and utilizing non-destructive tests for determining the concrete strength of these structures is essential. Ultrasonic pulse velocity test is one of the main methods of non-destructive testing in the assessment of compressive strength of concrete in the service area. The aim of this study is estimation of the compressive strength of lightweight aggregate concrete by offering suitable mathematical formulations. For this purpose, many samples of three different types of lightweight aggregate concrete are made and tested by concrete breaking machine and ultrasonic pulse velocity instrument. Then, some relationships are presented to predict the compressive strength of the concrete by using ultrasonic test results. Two different methods of fitting exponential function and Gene Expression Programming (GEP) are utilized to find the proper relationships. The results show that the exponential function has high accuracy in estimating the compressive strength of lightweight aggregate concrete made with natural pumices. But, it does not have good results for concrete made of expanded clay. However, the GEP has high accuracy for all the materials, and the experimental results are perfectly compatible with the test results.
\end{abstract}

(C) 2016 Sharif University of Technology. All rights reserved.

\section{Introduction}

In general, the main defect of non-destructive methods for evaluating the properties of concrete is that any bit of property of concrete being tested is influenced by several parameters. Besides, there is no meaningful physical relationship between what we expect from that characteristic of concrete and what the test shows. Therefore, using these methods in the evaluation of the desired characteristic of concrete (especially compressive strength) is faced with many errors. Also,

*. Corresponding author. Tel./Fax: +98 7137277656 E-mail addresses: hadianfard@sutech.ac.ir (M.A. Hadianfard); s.jafari@sutech.ac.ir (S. Jafari) they need to be supplied with the calibration graphs for every kind of concrete, which is costly and timeconsuming. Manufacturers of these devices often find an empirical relationship for their tests. Many of these relationships are not suitable for all types of concretes and require some modifications [1]. For this purpose, the use of mathematical and evolutionary models, such as fuzzy logic, neural networks, artificial intelligence, and genetic algorithm, which can be managed based on empirical studies, have been developed [1-3].

On the other hand, with the occurrence of events, such as earthquakes, fires, structural changes in the desired usage of the structure, uncertainty about the quality of concrete in structures due to a defect in construction, it is necessary to evaluate the strength 
of existing concretes. Thus, non-destructive tests, such as ultrasonic pulse velocity test, are very good choices to evaluate the strength of concrete in the existing buildings. Because these testes are easily conductible, cost-effective, and time-saving, they are considered by the engineers and researchers worldwide [3-5].

By conducting multiple tests on concrete samples, Facaoaru provided the pulse velocity ranging from different kinds of the aggregates [6]. Malhotra studied the velocity of the pulses in samples of concrete with different water-cement ratios and different types of aggregates [7]. Gaydecki et al. investigated the propagation and attenuation of ultrasonic pulses in concrete [8]. By studying the pulses passing from concrete specimens made with limestone aggregates with different qualities, Carcano and Moreno proposed a model to assess the quality of concrete [9]. Through artificial neural networks and using ultrasonic pulse velocity, Kewalramani and Gupta tried to predict the compressive strength of concrete and compared the results of neural networks and multiple variable regressions [2]. Through programming in MATLAB and considering the number of parameters of concrete, Trtnik et al. provided a model for concrete compressive strength based on neural networks and using ultrasonic pulse velocity [3]. Also, a new model was proposed by Mousavi et al. for predicting compressive strength of high performance concrete using gene expression programming [10].

The use of lightweight structural concrete to reduce the weight of earthquake resistant buildings is very useful and has many applications. Therefore, many researchers consider the research on the properties of different types of lightweight concretes and evaluation of concrete strength $[11,12]$.

According to the importance and application of structural lightweight aggregate (LWA) concretes in the earthquake resistant buildings, this study proposes some models to predict the compressive strength of the concrete by ultrasonic testing method, which is a nondestructive test. For this purpose, many samples of three different types of LWA concrete are made and tested. Then, important factors affecting the velocity of ultrasonic pulse in concrete are studied. Finally, two different methods of fitting exponential curve and Gene Expression Programming (GEP) are used to predict concrete strength. The proposed relationships are accurate, simple, and easy to use; they are applicable to the evaluation of the compressive strength of LWA concretes in the existing buildings.

\section{Experimental program}

To study the above-mentioned items, three types of lightweight aggregate concrete were made and tested. For convenience, each kind of concrete was named. The concrete made of expanded clay was named LWA01; the concrete made of natural (mineral) pumices with the maximum nominal size of $1 / 2$ inches was named LWA02; and the concrete made of natural pumices with the maximum nominal size of $3 / 4$ inches was named LWA03. In all kinds of these concretes, sand was used as fine aggregates; expanded clay, mineral pumice size $1 / 2$ inches, and mineral pumice size $3 / 4$ inches were used as coarse aggregate.

\subsection{Material properties and mix design}

Considering the fact that the typical fine sand is used in light concrete construction, before the amendment, the fineness modulus of the sand was 3.46 which reached 3 after sift and amendment. According to the experiments conducted, sand moisture content was 1\%. In the mix design, Saturated Surface Dry (SSD) condition is needed for the sand which was $6 \%$ water. Specific gravity of sand was $1717.65 \mathrm{~kg} / \mathrm{m}^{3}$. In the standard ASTM C330, there are some implications and requirements for gradation of lightweight aggregates. The gradation of aggregates is based on these requirements [13]. The lightweight aggregates used in this study were coarse aggregates with the sizes of $3 / 4$ inches $(19.2 \mathrm{~mm})$, and 0.5 inches $(12.8 \mathrm{~mm})$ for mineral pumices, and $3 / 8$ inches $(9.6 \mathrm{~mm})$ for expanded clay. Specific gravity for expanded clay was $365.72 \mathrm{~kg} / \mathrm{m}^{3}$. Also, specific gravity for mineral pumice with the nominal size of $1 / 2$ inches and $3 / 4$ inches was 693 and $653 \mathrm{~kg} / \mathrm{m}^{3}$, respectively. For expanded clays and mineral pumices, the humidity of aggregates in natural environment was zero in order to be put outside and exposed to the sun. Also, according to the conducted experiments, for the aggregates of expanded clays and mineral pumices to reach the SSD condition, $13 \%$ and $15 \%$ water is needed, respectively. Picnometric specific density factor for expanded clays was 1.1. Also, Picnometric specific density factor for mineral pumices with the size of $1 / 2$ inches and $3 / 4$ inches was 1.69 and 1.59 , respectively.

The lightweight aggregates were according to the standard ASTM C330 [13], and determination of the lightweight aggregate concrete mixing ratio was based on standard ACI 211.2 [14]. In this study, more than 100 concrete samples have been tested and it is impossible to present all mix designs. But, a summary of the concrete mix designs and densities of hardened concretes is presented in the Table 1 . All the weights were used for making $1 \mathrm{~m}^{3}$ of fresh concrete and all weights were based on Saturated Surface Dry (SSD) aggregates.

The measurement method of concrete compressive strength is according to the standard ASTM C 39$83 \mathrm{~b}$ [15]. Loading rate was considered constant ranging from 0.15 to $0.34 \mathrm{MPa} / \mathrm{sec}$. Therefore, the lab velocity of $0.3 \mathrm{MPa} / \mathrm{sec}$ was used to break the samples. 
Table 1. Summary of the concrete mix design and density of the lightweight concretes.

\begin{tabular}{|c|c|c|c|c|c|c|c|}
\hline $\begin{array}{l}\text { Name of } \\
\text { samples }\end{array}$ & $\begin{array}{l}\text { Type of } \\
\text { LWA }\end{array}$ & $\begin{array}{c}\text { Water } \\
\text { cement ratio }\end{array}$ & $\begin{array}{c}\text { Water } \\
W_{w}(\mathrm{~kg})\end{array}$ & $\begin{array}{l}\text { Cement } \\
W_{c}(\mathrm{~kg})\end{array}$ & $\begin{array}{c}\text { Sand } \\
W_{s}(\mathrm{~kg})\end{array}$ & $\begin{array}{c}\text { LWA } \\
W_{l}(\mathrm{~kg})\end{array}$ & $\begin{array}{l}\text { Density } \\
\left(\mathrm{kg} / \mathrm{m}^{3}\right)\end{array}$ \\
\hline \multirow{3}{*}{ LWA01 } & \multirow{3}{*}{ Expanded clay } & 0.4 & 210 & 525 & 710 & 155 & 1659 \\
\hline & & 0.6 & 230 & 380 & 835 & 155 & 1529 \\
\hline & & 0.8 & 210 & 260 & 975 & 155 & 1631 \\
\hline \multirow{3}{*}{ LWA02 } & \multirow{3}{*}{ Natural pumice $1 / 2$ in } & 0.4 & 212 & 530 & 737 & 371 & 1878 \\
\hline & & 0.6 & 212 & 353 & 913 & 371 & 1898 \\
\hline & & 0.8 & 212 & 265 & 1002 & 371 & 1836 \\
\hline \multirow{3}{*}{ LWA03 } & \multirow{3}{*}{ Natural pumice $3 / 4$ in } & 0.4 & 212 & 530 & 619 & 539 & 1718 \\
\hline & & 0.6 & 212 & 353 & 795 & 539 & 1840 \\
\hline & & 0.8 & 212 & 265 & 884 & 539 & 1781 \\
\hline
\end{tabular}

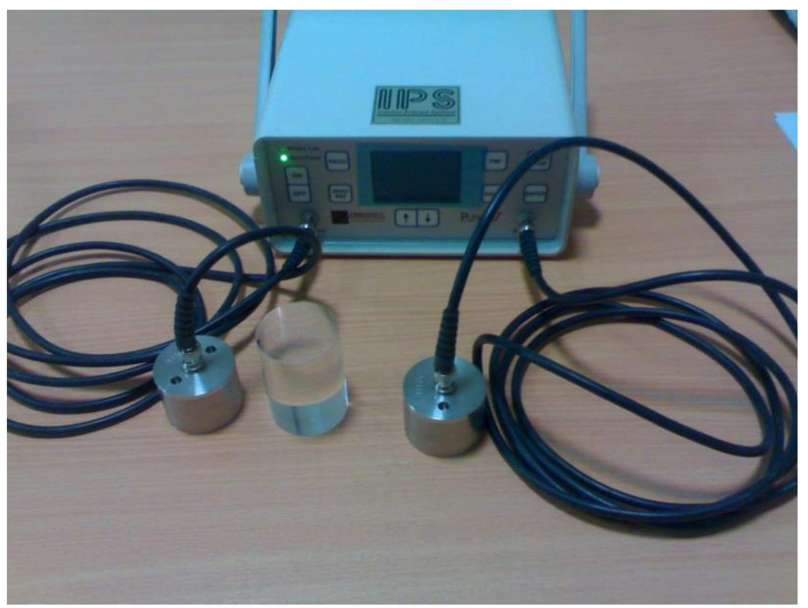

Figure 1. Ultrasonic testing device (pundit).

\subsection{Ultrasonic pulse velocity test}

Standard method of ultrasonic testing is conducted according to ASTM C 597 [16]. The frequency was $54 \mathrm{kHz}$ and the voltage was $500 \mathrm{~V}$ in conducting the test. Figure 1 shows the device. The device includes a processor unit that carries out sending and receiving ultrasonic pulses and measuring the time between the two operations (sending and receiving). Also, it includes two probes and two cables, which do the transmission of ultrasonic pulses. To calibrate the device, a standard glass cylinder was used.

The device is lightweight, portable, and easy to use and can also be used with or without electricity inside or outside of the lab. The device has two probes that actually transfers the sound energy. The probe sent to the concrete transmits the sound energy and the recipient probe receives this energy; the pulse flow rate is achieved according to the time difference between these two acts. As shown in Figure 2, in this study, the direct transfer (opposite surfaces) is used to measure the pulse flow rate.

\section{Experimental results}

\subsection{Factors affecting the ultrasonic pulse velocity}

Many factors affect the Velocity of ultrasonic pulse in concrete. Some of the most important factors considered in this paper are type of light weight aggregates, water-cement ratio $(\mathrm{W} / \mathrm{C})$, and the weight ratio of lightweight aggregate to all aggregates. All the factors mentioned above affect the strength of concrete and also affect the speed of the pulse.

Figure 3 shows the diagrams for direct transfer velocity of sound waves $(\mathrm{km} / \mathrm{s})$ and concrete compressive strength (MPa) for LWA concrete. This diagram indicates a clear understanding of the situation of lightweight concrete and also its compressive strength. By increasing the compressive strength, the velocity of the pulse increases too; it indicates that there is a direct relationship between them.

Figure 4 shows the diagrams for the direct transfer velocity of sound pulses with respect to different watercement ratios. This diagram shows that the increase of water-cement ratio will decrease the velocity of ultrasonic pulses and the compressive strength of concrete.

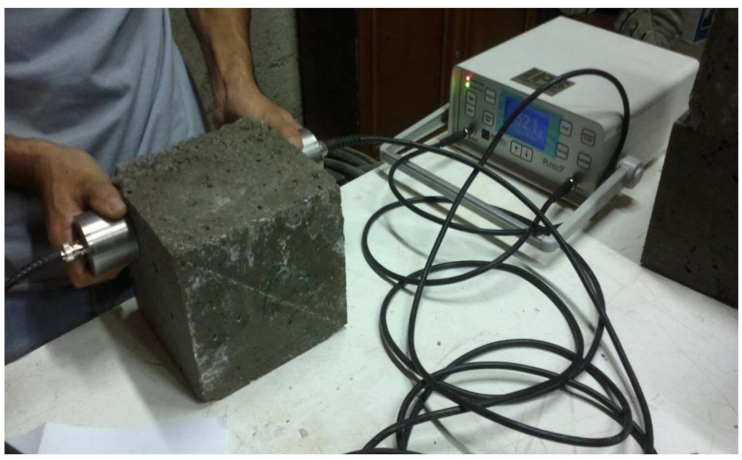

Figure 2. The velocity test for direct transmission of pulses. 


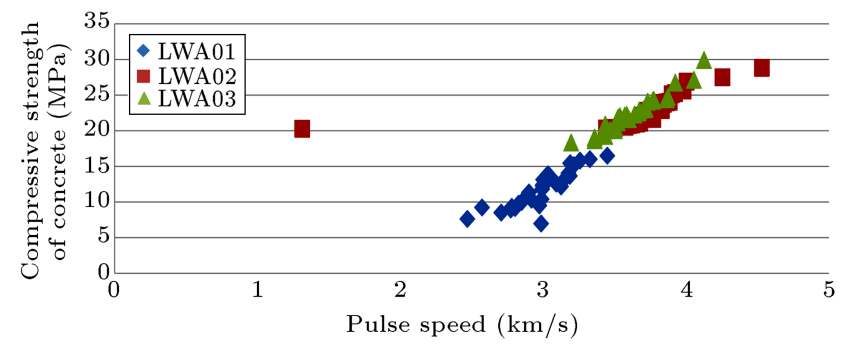

Figure 3. Compressive strength of concrete according to the direct transfer velocity of sound pulses for lightweight aggregate cxoncrete.

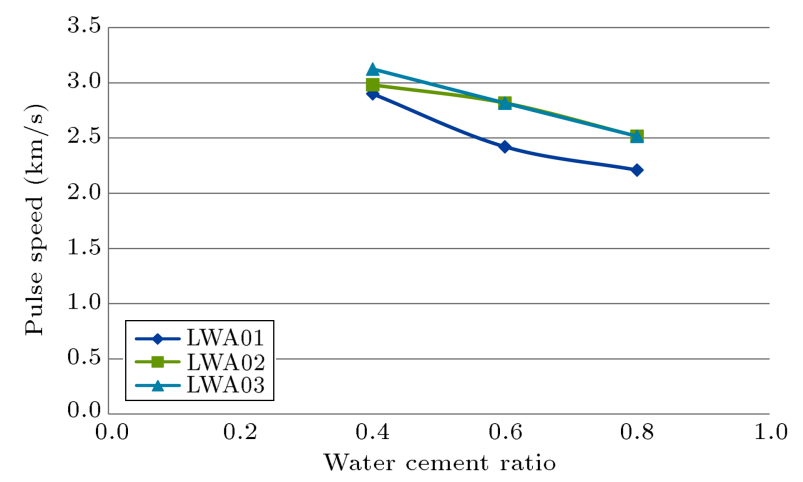

Figure 4. The direct transfer velocity of sound waves with respect to water cement ratio.

Figures 5 to 7 show the diagrams for direct transmission pulses velocity with respect to the weight ratio of lightweight aggregate to all aggregates for different water-cement ratios. Increasing the ratio of the lightweight aggregate in all 3 kinds of concretes decreases the velocity of ultrasonic pulses and the compressive strength of concrete.

\subsection{Prediction of compressive strength of concrete by fitting exponential function}

There is no exact and determined relationship between ultrasonic pulses velocity and compressive strength. Therefore, this relationship can be introduced by mea-

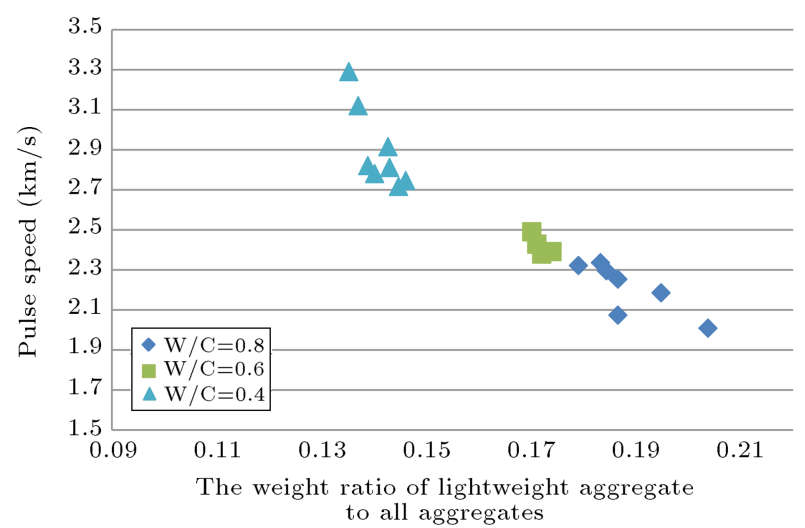

Figure 5. The velocity of sound pulses with respect to weight ratio of lightweight aggregate to all aggregates for different W/C for LWA01.

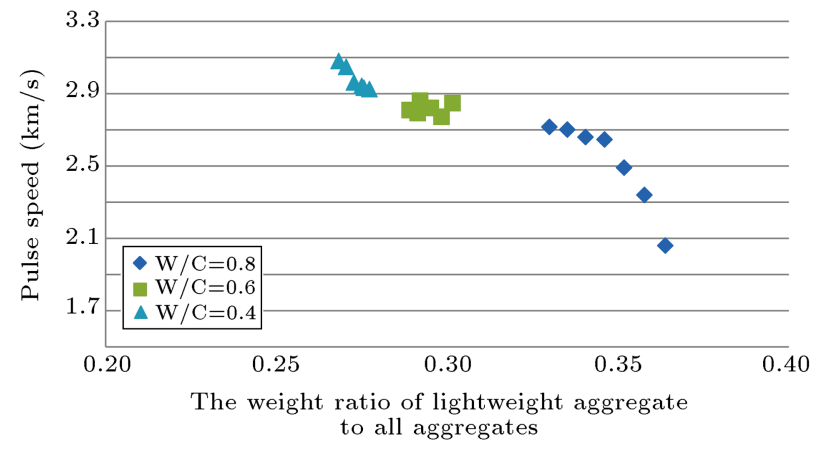

Figure 6. The velocity of sound pulses with respect to weight ratio of lightweight aggregate to all aggregates for different W/C for LWA02.

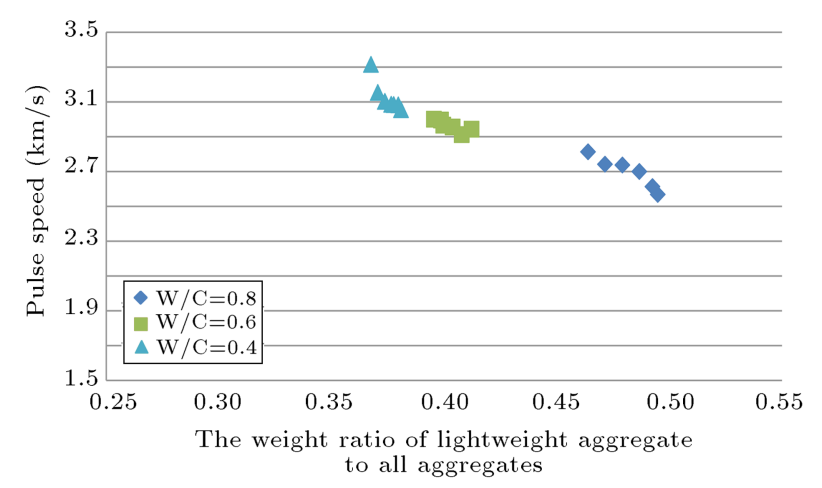

Figure 7. The velocity of sound pulses with respect to weight ratio of lightweight aggregate to all aggregates for different $\mathrm{W} / \mathrm{C}$ for LWA03.

suring and testing the velocity of ultrasonic pulses and the compressive strength of concrete [2].

To estimate the compressive strength according to the pulse rate, several relationships have been suggested. One of these relationships is an exponential function according to Eq. (1). These relationships are empirical, and their constant coefficients are empirically derived from multiple experiments $[3,4,17]$.

$$
F_{c}=A e^{B V} .
$$

In this relation, $F_{C}$ is concrete strength, $V$ is ultrasonic pulse velocity, and $A$ and $B$ are constants of curve fitting. This relationship, at first, has been proposed for estimating the compressive strength of normal concrete, but it can also be used for other concretes. The least squares method can be used to fit the diagram and to determine the constant coefficients $A$ and $B$. The method of least squares is a standard approach in regression analysis. In this method, a curve is sought to be fitted through a number of points. The best fit sense minimizes the sum of squares of the distances from the points to this curve. In this study, MATLAB software is used to perform the fitting.

To determine the accuracy of the obtained relationships and their compatibility with the experimental 
results, the correlation coefficient can be used. The correlation coefficient measures the strength and direction between two variables. The correlation coefficient is scaled so that it is always between -1 and +1 . When it is close to 0 , this means that there is little relation between the variables; when it is close to 1 , this means that there is a strong relation between the variables. In this study, the correlation coefficients are calculated between the results of experimental tests and the obtained results from the proposed mathematical formulations; they show the compatibility between the formulation and experimental results. Eq. (2):

The achieved relation for the LWA01 is shown in

$$
F_{c}=0.466 \times e^{V} .
$$

In this relation, the velocity of ultrasonic pulses is based on $\mathrm{km} / \mathrm{s}$ and the compressive strength of concrete at 28 days is based on MPa.

The correlation coefficient in this case is 0.76 ; it is not a very good result.

The achieved relation for the LWA02 is shown in Eq. (3):

$$
F_{c}=4.20 \times e^{-0.39 V} .
$$

The correlation coefficient in this case is 0.94 and it is acceptable.

Also, a wrong datum has been removed in this calculation.

The achieved relation for the LWA03 is shown in Eq. (4):

$$
F_{c}=2.55 \times e^{0.54 V} .
$$

The correlation coefficient in this case is 0.975 and it is acceptable.

Figures 8 to 10 show the diagrams for comparison of the above equations and the data obtained from the tests. According to these figures and the calculated correlation coefficients, it is found that the exponential functions have high accuracy in estimating the compressive strength of lightweight aggregate concrete made with natural (mineral) pumices. But, good results are not obtained for concrete made of expanded clay. As previously mentioned, the exponential relation initially was provided for normal concrete, then it may not be a good result for some concretes as for sample LWA01 in this paper. But, another method is proposed in the next section of this article, and it is based on GEP which is more accurate and has good correlation coefficients for all samples.

Also in this study, the transfer velocity of indirect ultrasonic pulses was measured and the results were analysed. But, the correlation coefficients were much smaller than 1, and the results were not reliable.

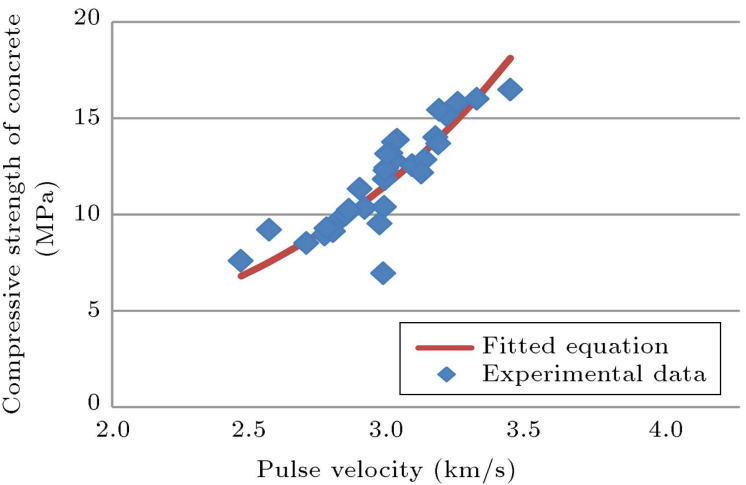

Figure 8. Function diagram with fitted equation for LWA01 concrete.

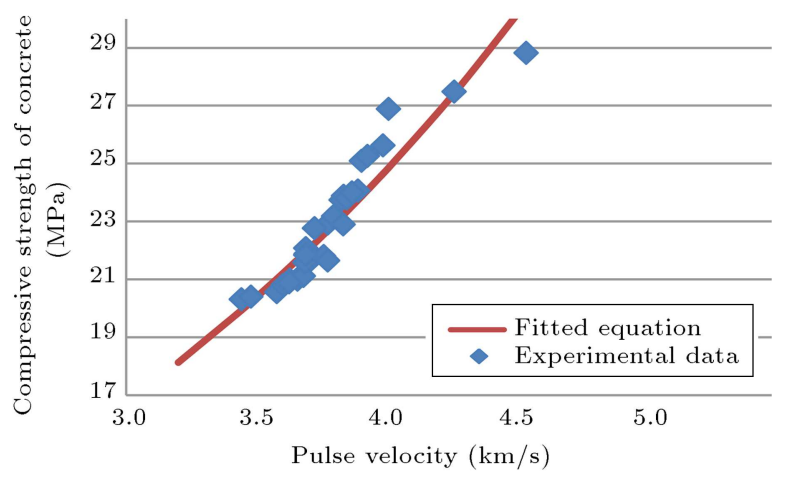

Figure 9. Function diagram with fitted equation for LWA02 concrete.

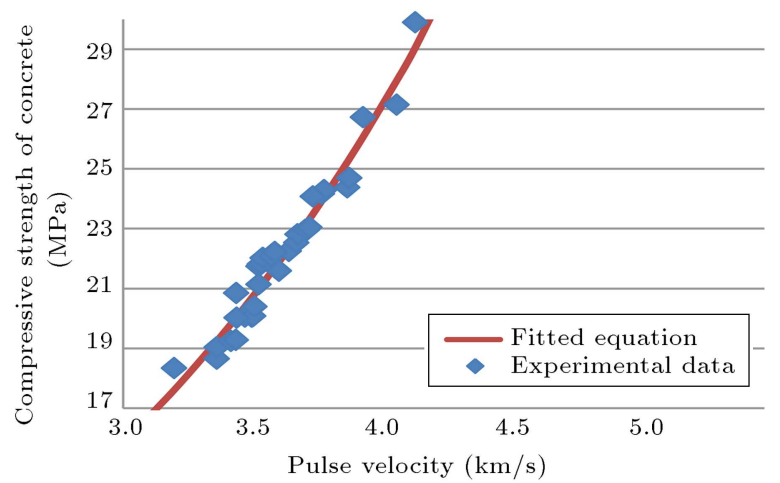

Figure 10. Function diagram with fitted equation for LWA03 concrete.

Considering the fact that the indirect pulse velocity is not dependent on the concrete parameters, so the results are ignored.

\subsection{Prediction of compressive strength of concrete using GEP}

This kind of programming is a genotype/phenotype genetic algorithm that is used as a new technology for producing computer programs (formulas). Linear chromosomes composed of genetic structure of genes are used in Gene Expression Programming (GEP). Chromosome function, like a genome, is modified by 
modulating devices such as a root replacement, gene replacement, gene composition, and one or two-point combination. Gene expression programming method is the same as Genetic Algorithms (GA) and Genetic Programming (GP) [18].

The gene expression programming method has been used to estimate the compressive strength of lightweight aggregate concrete. The fit function (namely, mean squared error) and the correlation coefficient are used to illustrate the accuracy of the relationship.

Eq. (5) is obtained for LWA01 concrete. In this equation, the velocity of ultrasonic pulses is according to $\mathrm{km} / \mathrm{S}$, and the compressive strength of the 28day concrete sample is according to $\mathrm{MPa}$. Also, the accuracy and the correlation coefficients are presented under Eq. (5):

$$
F_{c}=0.101 V-0.220
$$

Fitness function: MSE; Training fitness: 996.1; Training R-square: 0.96; Testing fitness: 993.8; Testing Rsquare: 0.96 .

Eq. (6) is obtained for LWA02 concrete. Also, the accuracy and the correlation coefficients are presented under Eq. (6):

$$
F_{C}=\frac{(2.061 V+2.47)^{(-4.12 V-7.28)}}{22.285}
$$

Fitness function: MSE; Training fitness: 996.85; Training R-square: 0.96; Testing fitness: 995.31; Testing Rsquare: 0.94 .

Eq. (7) is obtained for LWA03 concrete. Also, the accuracy and the correlation coefficients are presented under Eq. (7):

$$
F_{C}=\frac{-7.0602+(2.061 \mathrm{~V}+2.47)^{(-2.061 V-1.09)}}{22.285}
$$

Fitness function: MSE; Training fitness: 997.91; Training R-square: 0.97; Testing fitness: 996.47; Testing Rsquare: 0.95 .

All the above equations are simple and easy to use, but the offering of single relationship for all samples can be more applicable. Then, regarding the close relations obtained for each type of the laboratorymade concrete (LWA01, LWA02, and LWA03), Eq. (8) is obtained to estimate the compressive strength of total LWA concretes based on the velocity of direct pulses:

$$
F_{c}=V^{3.17}-e^{V}
$$

Fitness function: MSE; Training fitness: 997.51; Training R-square: 0.96; Testing fitness: 997.51; Testing R-square: 0.96 .

In Eq. (8), the velocity of ultrasonic pulses is based on $\mathrm{km} / \mathrm{s}$ and the compressive strength of 28-day cylindrical samples is measured based on MPa.

Figure 11 shows the diagram for the actual compressive strength and the estimated compressive strength based on the velocity of ultrasonic pulses. This graph shows that the experimental results are perfectly compatible with the results of Eq. (8). On the other hand, the correlation coefficient of this equation is 0.96 , which indicates the high accuracy of this proposed relationship. The advantage of Eq. (8) (compared to the fitted equations) by the method of the least sum of squares is that it is applicable to any kind of LWA concretes besides having a very high accuracy, while the fitted equations by the method of least sum of squares for each type of concrete is different. Table 2 shows the correlation coefficient of all obtained equations of the exponential function and GEP method. This table shows that the accuracy of

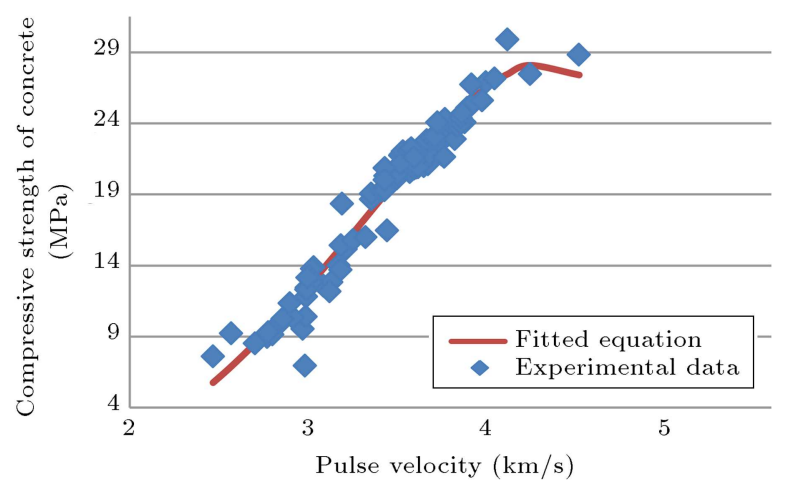

Figure 11. The actual compressive strength and the estimated compressive strength by GEP method.

Table 2. Comparing the correlation coefficients of obtained relations.

\begin{tabular}{cccc}
\hline $\begin{array}{c}\text { Concrete } \\
\text { type }\end{array}$ & $\begin{array}{c}\text { Exponential } \\
\text { function } \\
\text { Eqs.(2)-(4) }\end{array}$ & $\begin{array}{c}\text { Relationship } \\
\text { obtained from GEP } \\
\text { Eqs.(5)-(7) }\end{array}$ & $\begin{array}{c}\text { Relationship } \\
\text { obtained from GEP } \\
\text { Eq. (8) }\end{array}$ \\
\hline LWA01 & 0.76 & 0.96 & 0.96 \\
LWA02 & 0.94 & 0.96 & 0.96 \\
LWA03 & 0.97 & 0.97 & 0.96 \\
\hline
\end{tabular}


GEP method is much more than the fitted function. Also, in addition to the Eq. (8), the other equations obtained based on the GEP for three kinds of concretes (Eqs. (5)-(7)) have good accuracy and they have short, simple, and applicable relationships.

\section{Conclusions}

By examining the results of tests and presented graphs, it can be concluded that reducing the nominal maximum size of aggregate used in lightweight aggregate concrete will increase its density and compressive strength. Due to the fact that grain size of the expanded clays is smaller than the natural pumices, the concrete made of expanded clays has a smoother surface than concrete made of mineral pumices. For a specific material, increasing the maximum size of aggregates will decrease density and compressive strength of concrete. The reason for this phenomenon is that the increasing weakening of the aggregate structure is associated with an increase in maximum size.

The results of ultrasonic pulses tests show that the increase of the compressive strength will increase the velocity of these pulses. Increasing the weight ratio of lightweight aggregates to the total weight of all aggregates in the same water-cement ratio will decrease the velocity of ultrasonic pulses. Increasing watercement ratio will decrease the velocity of ultrasonic pulses. Also, the results show that for predicting the compressive strength of concrete by results of ultrasonic pulse velocity test, the method of fitting exponential function has high accuracy in estimating the compressive strength of lightweight aggregate concrete made with mineral pumices. But, it does not have good accuracy for the concrete made of expanded clay. However, the method of GEP has high accuracy for all the materials, and the experimental results are perfectly consistent with the test results. All the obtained relationships have simple and practical shape and can easily be used to estimate the compressive strength of existing concrete. To do so, it is needed to do some non-destructive ultrasonic test on existing concrete.

\section{References}

1. Nehdi, M., Chabib, H.E. and Naggar, A. "Prediction performance of self-compacting concrete mixtures using artificial neural networks", ACI Material Journal, 198(5), pp. 394-401 (2001).

2. Kewalramani, M.A. and Gupta, R. "Concrete compressive strength prediction using pulse velocity through artificial neural networks", Elsevier, Automation in Construction, 15(3), pp. 374-379 (2006).

3. Trtnik, G., Kavaciiĉ, F. and Turk, G. "Prediction of concrete strength using ultrasonic pulse velocity and artificial neural networks", Elsevier, Ultrasonic, 49(1), pp. 53-60 (2009).

4. Bungey, J.H. and Millard, S.G., Testing of Concrete in Structures, Third Ed. Blackie Academic \& Professional, an imprint of Chapman \& Hall (1996).

5. Sogbey, B.J.A.Y., Kwofie, S., Darko, E.O., Adiaottor, A.A., Allotey, N. and Dagadu, C.P.K. "Comparative structural strength analysis of pozzolana-Portland cement using ultrasonic non-destructive testing technique", E-Journal of Science \& Technology, 9(5), pp. 125-136 ( 2014).

6. Facaoaru, I. "Non-destructive testing of concrete in Romania", Symposium on NDT of Concrete and Timber, London: Institute of Civil Engineers, pp. 39-49 (1970).

7. Malhotra, V. "Nondestructive methods", Detroit. MI, ACI Monograph, 9 (1976).

8. Gaydecki, P., Burdekin, F., Damaj, W., John, D. and Payne, P. "The propagation and attenuation of medium frequency ultrasonic pulses in concrete", $A$ Signal Analytical Approach, MeasSciTechnol, 3, pp. 126-33 (1992).

9. Carcano, R.S. and Moreno, E.I. "Evaluation of concrete made with crushed limestone aggregate based on ultrasonic pulse velocity", Construction and Building Materials, 22, pp. 1225-1231 (2008).

10. Mousavi, S.M., Aminian, P., Gandomi, A.H., Alavi, A.H. and Bolandi, H. "A new predictive model for compressive strength of HPC using gene expression programming", Advances in Engineering Software, 45, pp. 105-114 (2012).

11. Gonen, T. "Mechanical and fresh properties of fiber reinforced self-compacting lightweight concrete", Scientia Iranica, A, 22(2), pp. 313-318 (2015).

12. Bogas, J.A., Gomes, M.G. and Gomes, A. "Compressive strength evaluation of structural lightweight concrete by non-destructive ultrasonic pulse velocity method", Ultrasonics, 53, pp. 962-972 (2013).

13. ASTM C330, Standard Specification for Lightweight Aggregates for Structural Concrete (2002).

14. ACI 211.2. "Standard practice for selecting proportions for structural light weight concrete", Reported ACI Committee 211.2 (1998).

15. ASTM C 39, Standard Test Method for Compressive Strength of Cylindrical Concrete Specimens (1983).

16. ASTM C 597, Standard Test Method for Pulse Velocity Through Concrete (2009).

17. Neville, A.M., Properties of Concrete, 3rd edition, Pitman publishing limited, London (1981).

18. Ferreira, C. "Gene expression programming: a new adaptive algorithm for solving problems", Complex Systems, 13(2), pp. 87-129 (2001). 


\section{Biographies}

Mohammad Ali Hadianfard was born in Shiraz, Iran in 1969. He obtained his BSc degree in Civil Engineering from Shiraz University, Iran in 1992. He continued his studies on Structures at Shiraz University and received his MSc and PhD degrees in 1995 and 2002, respectively. He is currently an Associate Professor of Civil Engineering. He has published about 25 journal papers. Also, he presented about 20 papers in the international and 70 papers in the national conferences. Moreover, he has contributed in writing 7 national standards of Iran. His research interests are: rehabil- itation, NDT of structures, blast loading, progressive collapse, steel connections and semi-rigid connections, nonlinear analysis, and structural reliability.

Saeed Jafari was born in Iran in 1988. He obtained his BSc degree in Mechanical Engineering of Agricultural Machinery from Razi University, Iran, in 2010. He obtained MSc degree in Earthquake Engineering from Shiraz University of Technology of Iran in 2012. He has presented 3 papers in international and national conferences. His research interests are concrete materials, concrete technology, and NDT of structures. 